\title{
Evaluation of S100B Protein in Patients with Schizophrenia with Seropositive and Seronegative Toxoplasma
}

\section{Toxoplasma Seropozitif ve Seronegatif Şizofreni Hastalarında S100B Proteininin Değerlendirilmesi}

\author{
Mustafa N. Namlı1, (D) Nuran Karabulut ${ }^{2}$, (1) Hakan Ayyıldız ${ }^{3}$ \\ ${ }^{1}$ Istanbul Health Directorate of Republic of Turkey Ministry of Health, Department of Public Inpatient Health Sevices 6rd, Istanbul, Turkey \\ 2University of Health Sciences Turkey, Başakşehir Çam and Sakura City Hospital, Clinic of Medical Virology, Istanbul, Turkey \\ ${ }^{3}$ Elazığ Fethi Sekin City Hospital, Medical Biochemistry Laboratory Medical Biochemistry Laboratory, Medical BioMedical Biochemistry \\ Laboratory Elazığ, Turkey
}

\begin{abstract}
Objective: $\mathrm{S} 100 \mathrm{~B}$ is a calcium-binding protein that is secreted from astrocytes and other glial cells in the central nervous system and may affect the growth and/or differentiation of neurons and astrocytes. The neuropathological studies in cell cultures of Toxoplasma gondii and postmortem studies in patients with schizophrenia revealed many glial abnormalities, particularly in astrocytes. This study aimed to evaluate S100B protein levels in patients with schizophrenia having seropositive and seronegative toxoplasma.

Methods: This study included 40 patients with schizophrenia and 39 healthy control groups, with 20 toxoplasma seropositive in each group. The patients' psychopathology were evaluated with the positive and negative syndrome scale (PANSS). S100B level and T. gondii immunoglobulin G (lgG) were analyzed by electrochemiluminescence immunoassay and the enzyme-linked immune-sorbent assay method, respectively.

Results: No significant difference was found in $\mathrm{S100B}$ values between the patients with schizophrenia and healthy controls ( $p=0.94$ ). No statistically significant correlations were found between S100B and both PANSS subscale scores and disease duration. S100B median values between toxoplasma lgG-positive and negative groups have no statistically significant difference in both healthy controls ( $p=0.38)$ and patients with schizophrenia $(p=0.93)$.

Conclusion: This study found no association between S100B protein levels and both schizophrenia and latent toxoplasma. Some studies report a role for S100B in schizophrenia; however, uncertainties still exist and are in some ways contradictory.
\end{abstract}

Keywords: Schizophrenia, S100B, toxoplasma

\section{öz}

Amaç: S100B, merkezi sinir sistemindeki astrositlerden ve diğer glial hücrelerden salgılanan, nöronların ve astrositlerin büyümesinde ve/veya farklılaşmasında rol oynayabilen kalsiyum bağlayıcı bir proteindir. Toxoplasma gondii hücre kültürlerinde yapılan nöropatolojik çalışmalarda ve şizofreni hastalarında yapılan postmortem çalışmalarda, özellikle astrositlerde olmak üzere birçok glial anormallik gösterilmiştir. Bu çalışmanın amacı, toksoplazma seronegatif ve seropozitif şizofreni hastalarında S100B protein düzeylerini değerlendirmekti.

Gereç ve Yöntem: Çalışmaya her grupta 20 toksoplazma seropozitif olmak üzere toplam 40 şizofreni hastası ve 39 sağlıklı kontrol grubu dahil edildi. Hastaların psikopatolojisi, pozitif ve negatif sendrom ölçeği (PANSS) ile değerlendirildi. S100B seviyesi ve T. gondii immünoglobulin (lgG), sırasıyla elektrokemilüminesans immünoassay yöntemi ve enzime bağlı immün-sorbent yöntemi ile analiz edildi.

Bulgular: Şizofreni hastaları ile sağlıklı kontroller arasında S100B değerlerinde anlamlı fark yoktu $(p=0,94)$. S100B ile hem PANSS skorları hem de hastalık süresi arasında istatistiksel olarak anlamlı bir ilişki yoktu. Toxoplasma immünoglobulin G (lgG) pozitif ve negatif gruplar arasında S100B medyan değerlerinde hem sağlıklı kontrollerde $(p=0,38)$ hem de şizofreni hastalarında $(p=0.93)$ istatistiksel olarak anlamlı bir fark yoktu.

Sonuç: Bu çalışmada, S100B protein seviyeleri ile hem şizofreni hem de latent toksoplazma arasında bir ilişki bulunmamıştır. Bazı çalışmalar S100B'nin şizofrenide bir rolü olduğunu bildirmektedir, ancak bu konuda belirsizlikler hala mevcuttur ve bazı yönlerden çelişkilidir.

Anahtar Kelimeler: Şizofreni, S100B, toxoplasma

Address for Correspondence: Nuran Karabulut, University of Health Sciences Turkey, Başakşehir Çam and Sakura City Hospital, Clinic of Medical Virology, Istanbul, Turkey

E-mail: nuranakarabulut@gmail.com ORCID ID: orcid.org/0000-0003-3550-2599

Cite as: Namlı MN, Karabulut N, Ayyıldı H. Evaluation of S100B Protein in Patients with Schizophrenia with Seropositive and Seronegative Toxoplasma. Med J Bakirkoy 2021;17:420-424

Received: 16.11.2021

Accepted: 06.12.2021 


\section{INTRODUCTION}

The etiology of schizophrenia remains largely unclear and is believed to be multifactorial. In the past two decades, numerous studies have been conducted to find a direct link between latent toxoplasmosis and schizophrenia. Toxoplasma gondii is a common protozoan parasite that infects one-third of the world's population. Toxoplasma showing neurotropism is a parasite that migrates within the brain tissue, predominantly in the gray matter, localizing in neurons, astrocytes, and microglia. Its dormant form, the bradyzoite, can persist in the host brain for many years and perhaps until death $(1,2)$.

Recently, numerous studies have suggested a link between schizophrenia and S100B protein. The S100 protein family that was described in the mid-1960s has been the subject of many studies in recent years. This protein family is called S100 since it is $100 \%$ soluble in ammonium sulfate and was originally purified from bovine brain and described as brain-specific (3). Currently, the S100 protein family consists of $>20$ calcium-binding proteins with structural similarities. Additionally, some members of the $\mathrm{S} 100$ protein family bind copper and/or zinc. S100B is secreted from many cells, i.e., astrocytes, oligodendrocytes, neurons, lymphocytes, or adipocytes. In physiological concentrations, S100B has neurotrophic and neuroprotective effects $(4,5)$. However, overproduction of $\mathrm{S} 100 \mathrm{~B}$ can lead to neurotoxicity and inhibit the proliferation and differentiation of neurons, and it can induce neurodegeneration and apoptosis (6). S100B secretion is increased by pro-inflammatory cytokines and this protein could be involved in the unstable inflammatory response that is observed in various central nervous system disorders, including schizophrenia, Alzheimer's disease, and major depression (7). Therefore, measuring the functionality of astrocytes in patients with schizophrenia via the S100B protein, which can be detected in both serum and cerebrospinal fluid (CSF) is important. This study aimed to compare serum S100B levels in toxoplasma seronegative and seropositive schizophrenia cases.

\section{METHODS}

\section{Participants}

This study included 40 patients with schizophrenia and 39 healthy control groups, with 20 toxoplasma seropositive in each group. The clinical diagnosis of patients with schizophrenia was made through the Diagnostic and Statistical Manual of Mental Disorders. The positive and negative syndrome scale (PANSS) was used to measure the symptoms of patients with schizophrenia. Exclusion criteria included patients with a history of meningitis, encephalitis, mental retardation, head trauma, substance abuse, alcoholism, and immunodeficiency diseases. The control group consisted of 39 healthcare workers without a history of schizophrenia or psychiatric disorders. This study was approved by the Firat University Ethical Committee (reference number: 08/12/26042016). The study was conducted following the Declaration of Helsinki.

\section{Laboratory Analysis}

Blood samples were obtained under sterile conditions from all study participants. Samples were stored at $-20^{\circ} \mathrm{C}$ until $\mathrm{T}$. gondii lgG and S100B test analyses after centrifugation. All samples for T. gondii immünoglobulin (lgG) detection were analyzed using a commercial enzyme-linked immunosorbent kit (Vircell, Granada, Spain) on the Triturus system (Grifols, Parets del Valles, Spain) following the manufacturer's instructions. T. gondii lgG levels below $10 \mathrm{IU} / \mathrm{mL}$ were considered negative, and levels above $10 \mathrm{IU} / \mathrm{mL}$ were considered positive. Serum S100B level was analyzed by electrochemiluminescence immunoassay method on Cobas 8000/e602 analyzer (Roche Diagnostics, Risch Rotkreuz, Switzerland) using Roche kit. The S100B measuring range is between $0.005 \mu \mathrm{g} / \mathrm{L}$ and $39 \mu \mathrm{g} / \mathrm{L}$.

\section{Statistical Analysis}

Statistical analyses were performed using the Statistical Package for the Social Sciences version 21.0 software (IBM Corp., Armonk, NY USA). The Kolmogorov Smirnov or Shapiro-Wilk test was used to determine the data normality distribution. Student's t-test or Mann-Whitney $U$ test was used to compare continuous variables between the groups. The Chi-square test or Fisher's Exact test was used for categorical comparisons between the different groups. The Pearson correlation or Spearman's rho test was used to analyze the correlation between the parameters. The $p$-value of $<0.05$ was considered statistically significant.

\section{RESULTS}

This study included 40 patients with schizophrenia, 20 females and 20 males, with ages ranging between 22 and 54 years. The control group consisted of 39 healthy healthcare workers, 20 females and 19 males, with ages ranging between 24 and 56 years. No statistically significant difference was found between patients with schizophrenia and healthy controls in terms of age and gender (Table 1). Illness duration in schizophrenia cases ranged from 5 months to 31 years, and the median duration was 12 years.

The median S100B values that are detected in schizophrenia and healthy control groups are shown in Table 1. No 
Table 1. Demographic, clinical, and laboratory characteristics of patients with schizophrenia and healthy controls

\begin{tabular}{|c|c|c|c|}
\hline & $\begin{array}{l}\text { Schizophrenia } \\
\text { patients }\end{array}$ & $\begin{array}{l}\text { Healthy } \\
\text { controls }\end{array}$ & $p$ \\
\hline Number of participants & 40 & 39 & - \\
\hline Age (mean $\pm S D)$ & $38.70 \pm 8.36$ & $38.97 \pm 8.11$ & 0.88 \\
\hline \multicolumn{4}{|l|}{ Gender } \\
\hline Male & 20 & 19 & 0.91 \\
\hline Female & 20 & 20 & \\
\hline T. gondii lgG positive, $\mathrm{N}$ & 20 & 20 & 0.91 \\
\hline S100B, rg/L (median) & 0.046 & 0.045 & 0.94 \\
\hline \multicolumn{4}{|l|}{ PANSS subscales } \\
\hline $\begin{array}{l}\text { Positive subscale score } \\
\text { (median) }\end{array}$ & 17 & - & - \\
\hline $\begin{array}{l}\text { Negative subscale score } \\
\text { (mean) }\end{array}$ & $29.89 \pm 8.11$ & - & - \\
\hline $\begin{array}{l}\text { General psychopathology } \\
\text { subscale score (mean) }\end{array}$ & $37.22 \pm 14.45$ & - & - \\
\hline PANSS total (median) & 91.50 & - & - \\
\hline
\end{tabular}

PANSS: Positive and negative syndrome scale, IgG: Immunoglobulin G, SD: Standard deviation

significant difference was found in S100B values between the two groups $(p=0.94)$. No correlations were determined between S100B values and PANSS positive $(r=0.24, p=0.15)$, PANNS negative $(r=-0.11, p=0.52)$, general psychopathology $(r=0.11, p=0.52)$, and PANNS total scores $(r=0.26, p=0.12)$ in the patients. No significant correlation was determined between disease duration and S100B level $(r=0.26, p=0.12)$.

Figure 1 shows healthy controls that were divided into two groups as Toxoplasma IgG positive and negative, in which S100B median value was higher in the positive group (0.047 $\mu \mathrm{g} / \mathrm{L})$ than in the negative group $(0.042 \mu \mathrm{g} / \mathrm{L})$, but this difference was not significant $(p=0.38)$. Similarly, in patients with schizophrenia, S100B median values were $0.046 \mu \mathrm{g} / \mathrm{L}$ and $0.045 \mu \mathrm{g} / \mathrm{L}$ in Toxoplasma lgG-positive and negative groups, respectively, without a statistically significant difference $(p=0.93)$.

\section{DISCUSSION}

S100B that has neurotrophic and neuroprotective effects is concentrated in astrocytes and other glial cell types, such as oligodendrocytes, Schwann cells, retinal Muller cells, ependymal cells, enteric glial cells, and certain subpopulations of neurons (5). S100B is thought to mediate interactions between the glial cells and between the neurons and glial cells, and it acts as a cytokine after being secreted from the glial cells $(8,9)$.

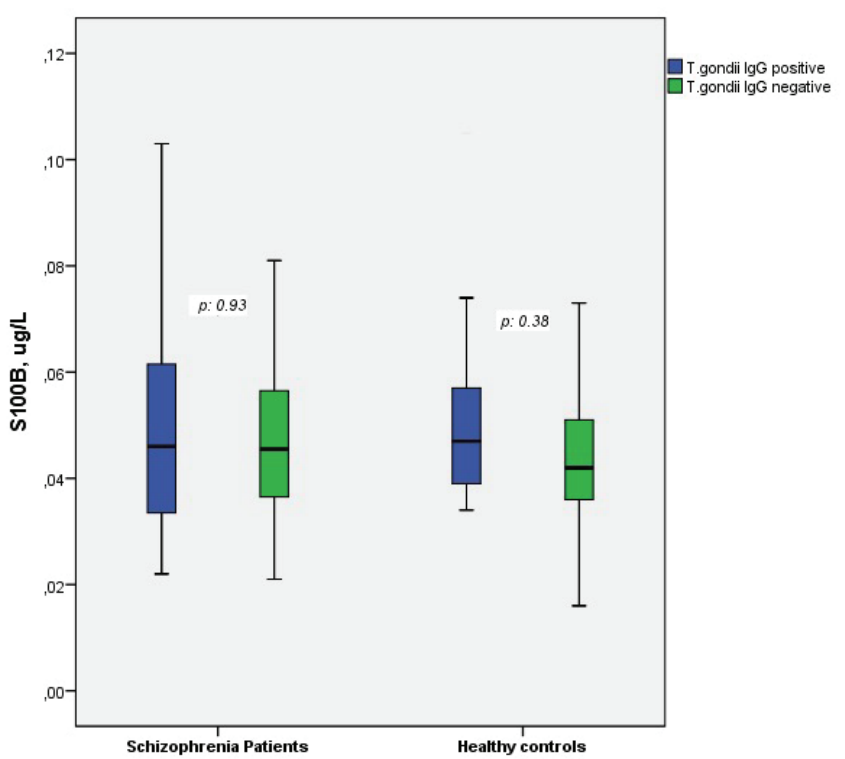

Figure 1. Comparison of S100B values in Toxoplasma gondii IgG positive and negative groups

IgG: Immunoglobulin G

Recently, various studies have suggested that the S100B protein is a biomarker of schizophrenia pathophysiology. Post mortem studies in patients with schizophrenia have shown that the S100 protein was upregulated in both the frontal cortex of patients with paranoid schizophrenia, but it was downregulated in the corpus callosum and deep white matter of the anterior cingulate gyrus (10-12). Previous studies that investigate the blood S100B levels in patients with schizophrenia revealed higher blood S100B levels in patients with schizophrenia than healthy control groups $(8,13,14)$. Contrarily, a study reported no correlation between S100B and schizophrenia and another reported the decreased levels of S100B in schizophrenia $(15,16)$. Additionally, serum S100B is reported to be elevated in drug-free and drug-naive patients with schizophrenia, and in the early phase of the disease $(14,17)$. This study revealed no significant difference in $\mathrm{S100B}$ values between the schizophrenia and control groups. The study consisted of patients with chronic schizophrenia with median disease duration of 12 years, which may be a factor in the absence of a significant change in $\mathrm{S100B}$ values.

Data about S100B and psychopathology are controversial. A meta-analysis study revealed an inclusive relationship between S100B and psychopathology, whereas most studies did not find any relationship, and a negative correlation was found between PANNS negative and S100B, whereas a positive correlation in a few studies (7). This study revealed no significant correlation between the PANSS total or any PANSS subscale score and S100B. 
A consensus was not determined on the effect of disease duration on S100B levels. Almost all studies reported no association between S100B concentrations and disease duration (9). Similarly, no relationship was also found between disease duration and S100B in this study. Only one study reported a negative correlation between S100B levels and disease duration (14).

Many studies reported a possible relationship between Toxoplasmaandschizophrenia(18). Invitroneuropathological studies in cell cultures of $T$. gondii and post mortem studies on the brains of patients with schizophrenia revealed many glial abnormalities, particularly in astrocytes (19). No study has found a relationship between this parasite, which can remain dormant in the brain for years, and S100B, which shows the astroglial and microglial activation. This study found no significant difference was found between toxoplasma and S100B levels in both schizophrenia and healthy control groups.

\section{Study Limitations}

S100B could leak into the systemic circulation and CSF in the event of neuronal injury and blood-brain barrier disruption (20). CSF was not taken from the patients since it required an invasive procedure. Investigating the level of S100B in CSF instead of serum may be more valuable. The study population was relatively small, thus it should be repeated in the larger population.

\section{CONCLUSION}

Our study revealed no association between S100B protein levels and both schizophrenia and latent toxoplasma. The information regarding the behavior of this protein in the brain is lacking, thus uncertainties still exist and are in some ways contradictory.

\section{ETHICS}

Ethics Committee Approval: The study was approved by the Firat University Ethical Committee (approval number: 08/12/26042016).

Informed Consent: Informed consent was obtained from all individual study participants.

\section{Authorship Contributions}

Concept: M.N.N., N.K., Design: M.N.N., Data Collection or Processing: M.N.N., N.K., H.A., Analysis or Interpretation: M.N.N., N.K., H.A., Literature Search: N.K., H.A., Writing: M.N.N., N.K.

Conflict of Interest: No conflict of interest was declared by the authors.
Financial Disclosure: The authors declared that no financial support was received in this study.

\section{REFERENCES}

1. Chaudhury A, Ramana BV. Schizophrenia and bipolar disorders: The Toxoplasma connection. Trop Parasitol 2019;9:71-6.

2. Xiao J, Prandovszky E, Kannan G, Pletnikov MV, Dickerson F, Severance EG, et al. Toxoplasma gondii: Biological Parameters of the Connection to Schizophrenia. Schizophr Bull 2018;44:983-92.

3. Moore BW. A soluble protein characteristic of the nervous system. Biochem Biophys Res Commun 1965;19:739-44.

4. Kozłowska E, Brzezińska-Błaszczyk E, Agier J, Wysokiński A, Żelechowska P. Alarmins (IL-33, sST2, HMGB1, and S100B) as potential biomarkers for schizophrenia. J Psychiatr Res 2021;138:380-7.

5. Michetti F, D’Ambrosi N, Toesca A, Puglisi MA, Serrano A, Marchese $E$, et al. The S100B story: from biomarker to active factor in neural injury. J Neurochem 2019;148:168-87.

6. Van Eldik LJ, Wainwright MS. The Janus face of glial-derived S100B: beneficial and detrimental functions in the brain. Restor Neurol Neurosci 2003;21:97-108.

7. Aleksovska K, Leoncini E, Bonassi S, Cesario A, Boccia S, Frustaci A. Systematic review and meta-analysis of circulating S100B blood levels in schizophrenia. PLoS One 2014;9:e106342.

8. Qi LY, Xiu MH, Chen DC, Wang F, Kosten TA, Kosten TR, et al. Increased serum S100B levels in chronic schizophrenic patients on long-term clozapine or typical antipsychotics. Neurosci Lett 2009;462:113-7.

9. Yelmo-Cruz S, Morera-Fumero AL, Abreu-González P. S100B and schizophrenia. Psychiatry Clin Neurosci 2013;67:67-75.

10. Steiner J, Bernstein HG, Bielau H, Farkas N, Winter J, Dobrowolny $\mathrm{H}$, et al. S100B-immunopositive glia is elevated in paranoid as compared to residual schizophrenia: a morphometric study. J Psychiatr Res 2008;42:868-76.

11. Steiner J, Schmitt A, Schroeter ML, Bogerts B, Falkai P, Turck CW, et al. S100B is downregulated in the nuclear proteome of schizophrenia corpus callosum. Eur Arch Psychiatry Clin Neurosci 2014;264:311-6.

12. Katsel P, Byne W, Roussos P, Tan W, Siever L, Haroutunian V. Astrocyte and glutamate markers in the superficial, deep, and white matter layers of the anterior cingulate gyrus in schizophrenia. Neuropsychopharmacology 2011;36:1171-7.

13. Deng H, Kahlon RS, Mohite S, Amin PA, Zunta-Soares G, Colpo GD, et al. Elevated Plasma S100B, Psychotic Symptoms, and Cognition in Schizophrenia. Psychiatr Q 2018;89:53-60.

14. Lara DR, Gama CS, Belmonte-de-Abreu P, Portela LV, Gonçalves CA, Fonseca M, et al. Increased serum S100B protein in schizophrenia: a study in medication-free patients. J Psychiatr Res 2001;35:11-4.

15. Uzbay T, Goktalay G, Kayir H, Eker SS, Sarandol A, Oral S, et al. Increased plasma agmatine levels in patients with schizophrenia. J Psychiatr Res 2013;47:1054-60.

16. Gattaz WF, Lara DR, Elkis H, Portela LV, Gonçalves CA, Tort AB, et al. Decreased S100-beta protein in schizophrenia: preliminary evidence. Schizophr Res 2000;43:91-5.

17. Chen S, Tian L, Chen N, Xiu M, Wang Z, Yang G, et al. Cognitive dysfunction correlates with elevated serum S100B concentration in drug-free acutely relapsed patients with schizophrenia. Psychiatry Res 2017;247:6-11. 
18. Torrey EF, Bartko JJ, Lun ZR, Yolken RH. Antibodies to Toxoplasma gondii in patients with schizophrenia: a meta-analysis. Schizophr Bull 2007;33:729-36.

19. Yuksel P, Alpay N, Babur C, Bayar R, Saribas S, Karakose AR, et al. The role of latent toxoplasmosis in the aetiopathogenesis of schizophrenia--the risk factor or an indication of a contact with cat? Folia Parasitol (Praha) 2010;57:121-8.
20. Moss BP, Patel DC, Tavee JO, Culver DA. Evaluating S100B as a serum biomarker for central neurosarcoidosis. Respir Med 2020;162:105855 